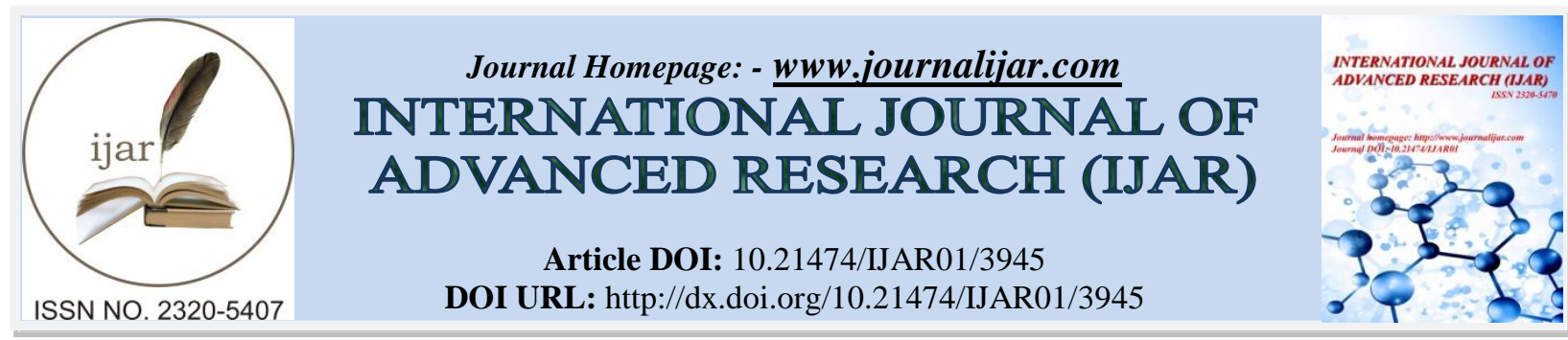

RESEARCH ARTICLE

\title{
SPECTROSCOPIC DETERMINATION OF SOME HEAVY METALS AND THEIR EFFECT ON THE QUALITY OF GROUNDWATER.
}

\author{
R. M. Abd El-aal ${ }^{1}$, W. H. Hegazy ${ }^{1}$, I. A. Ibrahem ${ }^{2 *}$ and M. A. Esmail ${ }^{1}$. \\ 1. Chemistry Department, Faculty of science, Suez University, Suez city, Egypt. \\ 2. Chemistry Department, Faculty of Science, Al-Azhar University, Nasr City, Cairo, Egypt.
}

\section{Manuscript Info}

Manuscript History

Received: 09 February 2017

Final Accepted: 06 March 2017

Published: April 2017

Key words:-

Spectroscopic determination,

Atomic absorption, Groundwater,

Upperegypt, Heavy metals

\begin{abstract}
Heavy metal contamination of the groundwater of Upper Egypt was described. The groundwater samples were analyzed for some heavy metals ( $\mathrm{Mn}, \mathrm{Fe}, \mathrm{Cu}, \mathrm{Zn}, \mathrm{Cd}$, and $\mathrm{Pb}$ ), by atomic absorption. Determine the water quality of ground water which is used for drinking and agriculture operations in the study area. Water samples from fourteen groundwater wells were collected for one year period (October 2014 to September 2015). According to WHO limited for drinking water, results showed that only the concentration of $\mathrm{Cu}$ and $\mathrm{Zn}$ are within the saving values. On the other hand concentration of $\mathrm{Mn}, \mathrm{Fe}, \mathrm{Zn}, \mathrm{Cd}$ and $\mathrm{Pb}$ are found to be higher than the allowed WHO limits of the water samples analyzed. The autumn months record the highest concentration for each $\mathrm{Mn}, \mathrm{Fe}, \mathrm{Cd}$ and $\mathrm{Pb}(3.58,10.09,1.04$ and $14.08 \mathrm{mg} / \mathrm{l})$ respectively, denoting that metal concentration in the wells vary significantly with sampling time. From the data we can observed that concentrations of the heavy metals vary significantly between the different ground water wells, indicating that the wells are different from each other in terms of heavy metal content. The results of this study suggest a possible risk to the population of the study area given the toxicity of these metals, and the fact that for many people in the study area, ground water is a main source of their water supply.
\end{abstract}

Copy Right, IJAR, 2017,. All rights reserved.

\section{Introduction:-}

Heavy metal contaminations are a problem associated with several areas of intensive industry. High concentration of the heavy metal ions is more toxic to human, even deadly. Groundwater contamination with heavy metals is one of the most important environmental issues as they are toxic even at low concentrations. Human activities have increased the concentrations of heavy metals in the environment. For example, anthropogenic activities e.g. industry, agriculture, solid waste disposal increase the con- tents of heavy metals in different environmental matrices (e.g. water, soil, air), fruits, vegetables, fish. etc. [1-5].

Lower concentrations of the heavy metals are common in our environment and necessary for good health, but large amounts cause acute or chronic toxicity. The hazardous includes cancer, organ damage, and nervous system. When heavy metals are digested by the human body, they form complexes with proteins already existing in the body. The formation of these complexes is very dangerous to human health because amine $\left(-\mathrm{NH}_{2}\right)$, thiol $(-\mathrm{SH})$ and carboxylic acid $(-\mathrm{COOH})$ groups are involved in the process. The bond created between the metals and these groups alter the 
natural structure of proteins. In addition, this bond destroys the molecules as they fail to perform their function correctly due to cell death. This in turn affects the catalytic characteristics of enzymes in general, which could lead to the formation of radicals that are very harmful due to their ability to oxidize the biological molecules present in the human body [6-10]. Egyptian laws for environmental affairs are correlated with protecting water resources from contamination and it determines the safe values of components and components found in water [11] table 1-1.

Table 1-1:- regulations from the ministry of water resources and irrigation discharge in the Nile River \& groundwater aquifers.

\begin{tabular}{|c|c|}
\hline Heavy metal & Maximum limits of Criteria and Specifications \\
\hline Manganese & $<\mathbf{0 . 0 5} \mathrm{mg} / \mathrm{L}$ \\
\hline Iron & $<1 \mathrm{mg} / \mathrm{L}$ \\
\hline Copper & $<1 \mathrm{mg} / \mathrm{L}$ \\
\hline Zink & $<\mathbf{0 . 0 2} \mathrm{mg} / \mathrm{L}$ \\
\hline Cadmium & $<\mathbf{0 . 0 0 3} \mathrm{mg} / \mathrm{L}$ \\
\hline Lead & $<\mathbf{0 . 0 0 1} \mathrm{mg} / \mathrm{L}$ \\
\hline
\end{tabular}

Many studies have investigated the presence and several determination methods of heavy metals in ground water and their effect on drinking water [12-16]. The world Health organization (WHO) estimates that about quarter of the diseases facing man kind to day occur due to prolonged exposure to environmental pollution [17]. Improper management of solid waste is one of the main causes of environmental pollution and degradation in many cities , especially in developing countries many of these cites lack solid most regulations and proper disposal facilities ,including for harmful waste. Such waste may be infection, toxic or radioactive [18]. Municipal waste dumping sites are designated places set aside for waste disposal. waste management poses a great challenge to the well -being of city residents, particularly those living adjacent the dumpsites due to the potential of the waste to pollute water, food sources of waste thus leads to environmental degradation, destruction. Depending on cities level of waste management, such waste may be dumped in uncontrolled manner, segregated for recycling purposes, or simply burnt .poor of the ecosystem and poses great risks to public health [19]. Generally, salt, salinity, sea water intrusion, lateral migration, vertical seepage, hazardous waste disposal sites, underground storage tanks, urban storm water runoff, mine drainage, wells and oil-field brines are the major sources of heavy metals for ground water contamination [20]. In this work, emphasis was placed on the use of spectral analysis method to identify and identify the heavy elements in the groundwater in the region located between Esna in Luxor governorate and El Sebaeya in Aswan governorate and knowledge of the negative effects of high concentrations of these metals in health and economic aspects. The study of the effect of these elements on water quality in the study area and extent its power to drink and agriculture processes

\section{Sampling and Methodology:-}

The groundwater samples were collected from 14 wells in the Upper Egypt area in the region between Esna -Luxor Governorate and Al-Sebaeya- Aswan Governorate fig. 2-1.

Sebaeya city in Aswan in where some minerals are extracted and concentrated, the most important phosphate ores which are continuously drilled and changed geology of the soil to complete the extraction and washing to increase the concentration of phosphate ores. It is also, based groundwater in Sebaeya-Aswan \& Esna (east \& West) - Luxor there are different types of agriculture crops which bear water salinity like Clover, Hibiscus, Sugar cane and Herbal plant.

The study was conducted over a full year from October 2014 to September 2015 (fig. 2-1). Samples were drawn from almost constant depth and equal size. Heavy metal analysis on groundwater was done to analyze of manganese $(\mathrm{Mn})$, iron $(\mathrm{Fe})$, copper $(\mathrm{Cu})$, zinc $(\mathrm{Zn})$ cadmium $(\mathrm{Cd})$, and lead $(\mathrm{Pb})$. These samples were analyzed by using Atomic Absorption /Fiaz model- PERKIN ELMER. (Nasser Lake Development Authority). Furthermore, the water quality is assessed and the associated risk based on the results obtained is then calculated. AAS is considered to be the most efficient and fastest growing trace element analytical technique. 


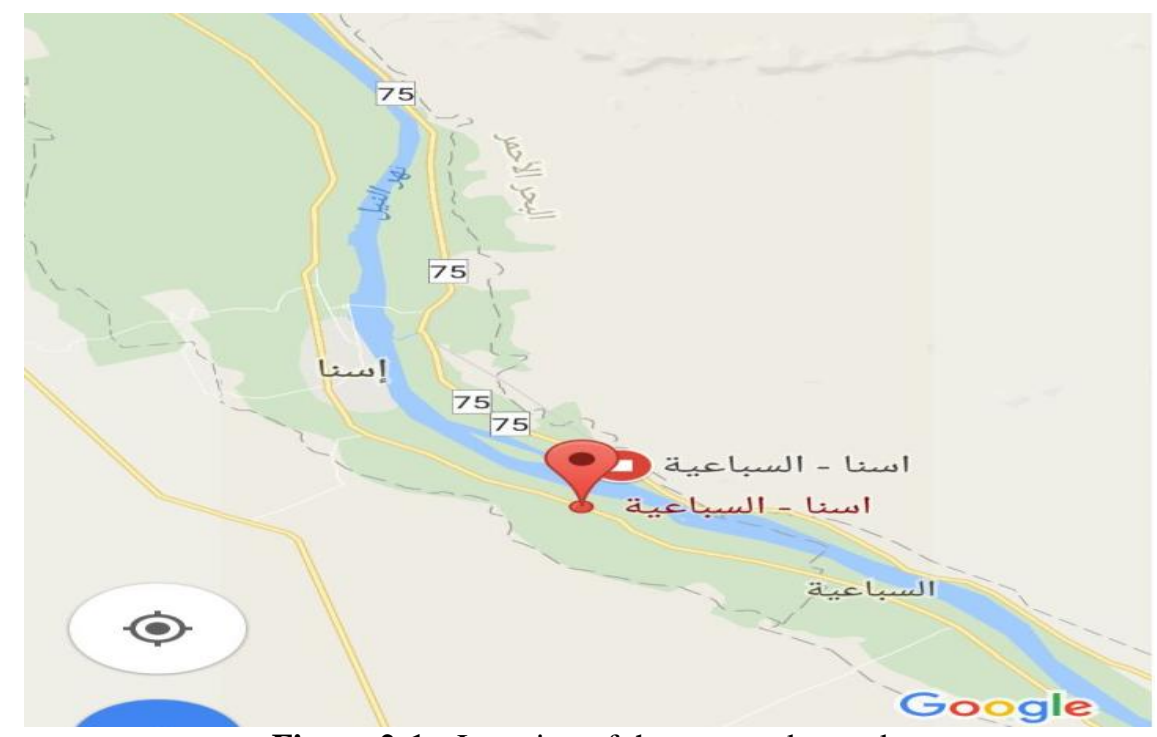

Figure 2-1:- Location of the area under study

\section{Results and Discussion:-}

Atomic Absorption Spectroscopy is a useful tool to determine trace elements in aqueous solutions. Table 2 shows the content found in groundwater as well as the maximum allowable limits for the concentration of hazardous heavy metals in drinking water set by egyption laws and different international organizations. Assessing the risks on human health resulting from exposure is further discussed.

\section{Manganese:-}

Manganese $(\mathrm{Mn})$ is metal that occur naturally in soils, rocks and minerals. In the aquifer, groundwater comes in contact with these solid materials dissolving them, releasing their constituents, including Mn, to the water. At concentrations approaching $0.05 \mathrm{mg} / \mathrm{L} \mathrm{Mn}$, the water's usefulness may become seriously impacted, e.g., there may be a metallic taste to the water and staining of plumbing fixtures may become common. At these concentrations, however, the health risk of dissolved Mn in drinking water is insignificant. If the round water is oxygen poor, manganese will dissolve more readily, particularly if the $\mathrm{pH}$ of the water is on the low side (slightly more acidic). Dissolved oxygen content is typically low in deep aquifers, particularly if to prevent the use of iron in the regeneration of blood hemoglobin. The toxicity not the aquifer contains organic matter. Dissolved manganese may form blackish particulates in the water and cause similar colored stains on fixtures [21, 22].

The manganese concentration $(3.58 \mathrm{mg} / \mathrm{l})$ is lower than the maximum permissible limit set by the Egyptian government $(0.05 \mathrm{mg} / \mathrm{l})$ Table 3-1 a, b, fig. 3-1. Autumn season have the highest concentrations, including most of the wells, indicating that the high concentrations are not affected by the nature of the region. High concentrations of manganese are due to the complex nature of manganese salts, making it difficult to process the spinach, which have the characteristics of rocky geology in the surface layers

\section{Iron:-}

Iron concentrations in surface and groundwater commonly exceed water quality standards. Iron occurs naturally in volcanic rocks, associated soils, and alluvial sediments of volcanic origin. The extent to which Fe dissolve in groundwater depends on the amount of oxygen in the water and, to a lesser extent, upon its degree of acidity, i.e., its $\mathrm{pH}$. Iron, for example, can occur in two forms: as $\mathrm{Fe}^{2+}$ and as $\mathrm{Fe}^{3+}$. When levels of dissolved oxygen in groundwater are greater than 1- $2 \mathrm{mg} / \mathrm{l}$, iron occurs as $\mathrm{Fe}^{3+}$, while at lower dissolved oxygen levels, the iron occurs as Fe ${ }^{2+}$. Although $\mathrm{Fe}^{2+}$ is very soluble, $\mathrm{Fe}^{3+}$ will not dissolve appreciably. If the groundwater is oxygen poor, iron will dissolve more readily, particularly if the $\mathrm{pH}$ of the water is on the low side (slightly more acidic). Dissolved oxygen content is typically low in deep aquifers, particularly if the aquifer contains organic matter. Decomposition of the organic matter depletes the oxygen in the water and the iron dissolves as $\mathrm{Fe}^{2+}$. Under these conditions, the dissolved iron is often accompanied by dissolved manganese or hydrogen sulfide (rotten egg smell). When this water is pumped to the surface, the dissolved iron reacts with the oxygen in the atmosphere, changes to $\mathrm{Fe}^{3+}$ (i.e., is oxidized and forms rust-colored iron minerals [21, 22]. 
The iron concentration $(10.09 \mathrm{mg} / \mathrm{l})$ is lower than the maximum permissible limit set by the Egyptian government $(0.05 \mathrm{mg} / \mathrm{l})$. Spring and autumn seasons have the highest concentrations, including most of the wells, indicating that the high concentration are not affected by the nature of the region, and we find these high concentrations in well water, which are located within the aquifers, which have the characteristics of rocky geology in the surface layers and also in the deep layers, Layers are aerobic. The data of the iron concentration showed in table 3-2 a, b and fig. 32

\section{Copper:-}

Copper forms strong solution complexes with humic acids. The affinity of $\mathrm{Cu}$ for hamates increases as $\mathrm{pH}$ increases and ionic strength decreases. In anaerobic environments, when sulfur is present $\mathrm{CuS}(\mathrm{s})$ will form. Copper mobility is decreased by sorption to mineral surfaces. $\mathrm{Cu}^{2+}$ sorbs strongly to mineral surfaces over a wide range of $\mathrm{pH}$ values. The cupric ion $\left(\mathrm{Cu}^{2+}\right)$ is the most toxic species of copper. Copper toxicity has also been demonstrated for $\mathrm{CuOH}^{+}$ and $\mathrm{Cu}_{2}(\mathrm{OH})_{2}{ }^{2+}[23]$. The copper concentration $(0.20 \mathrm{mg} / \mathrm{l})$ is lower than the maximum permissible limit set by the Egyptian government (3 mg/l) Table 3-3a, b, fig. 3-3. The highest concentration of copper is found in winter in the first four wells due to the relative difficulty of zinc salts because of some rocks in these wells. In general, there is no effective effect of zinc element concentrations on water quality in this region

\section{Zinc:-}

Zinc is an essential element in all living organisms. Nearly 200 zinc - containing enzymes have been identified. Acute toxicity of zinc arises from the ingestion of excessive amount of salts, either accidentally or deliberately as an ematic or dietary supplement [24].

The zinc concentration $(0.25 \mathrm{mg} / \mathrm{l})$ is lower than the maximum permissible limit set by the Egyptian government ( 5 $\mathrm{mg} / \mathrm{l}$ ). Table 3-4 a, b, fig. 3-4. Zinc concentrations were established almost constant in all seasons of the year and for all wells studied, the recorded values indicate that there is no risk of the presence of zinc in this area due to the difficulty of zinc salts compared with the rest of the elements.

\section{Cadmium:-}

The solubility of cadmium in water is influenced to a large degree by its acidity, suspended or sediment- bound cadmium may dissolve when increase in the acidity. A relationship between chronic occupational exposure to cadmium or chronic oral exposure to cadmium via the diet $\mathrm{n}$ concentration area and hypertention could be demonstrated [25].

The cadmium concentration $(1.04 \mathrm{mg} / \mathrm{l})$ is higher than the maximum permissible limit set by the Egyptian government $(0.005 \mathrm{mg} / \mathrm{l})$ Table 3-5 a, b, fig. 3-5 . The recorded results show that high concentrations of lead include all seasons of the year and maximum in autumn, This is due to the increase in the percentage of salts in this region due to some industries and surrounding activities.

\section{Lead; -}

The ingestion of lead is very dangerous to human health because it destroys the immune system, leaving the body vulnerable to all kinds of diseases. Recent studies indicate that exposure to lead is particularly harmful for children. Aside from the carcinogenic effects, continuous exposure is related to brain disorders and deterioration leading to learning disabilities [25]. The lead concentration $(14.08 \mathrm{mg} / \mathrm{l})$ is higher than the maximum permissible limit set by the Egyptian government $(0.05 \mathrm{mg} / \mathrm{l})$ table 3-6 a, b, fig. 3- 6 .

The recorded results show that high concentrations of lead include all seasons of the year and maximum in autumn, this is due to the increase in the percentage of salts in this region due to some industries and surrounding activities. 
Table 3-1:- a Monthly Variation For Manganese (II) For The Ground Water Samples Taken From West Esna(Luxor) Passing By Est Esna (Luxor) Finally By West Sebaeya (Aswan) (Oct.2014 - Sep. 2015 )

\begin{tabular}{|c|c|c|c|c|c|c|c|c|c|c|c|c|c|}
\hline \multicolumn{2}{|c|}{ Sample(weels) } & October & November & December & January & Febrauray & Marsh & April & May & June & July & Augest & September \\
\hline \multirow{4}{*}{ 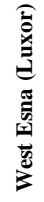 } & 1 & 0.35 & 0.19 & 0.3 & 0.1 & 0.33 & 0.14 & 0.11 & 0.12 & 0.13 & 0.13 & 0.11 & 0.28 \\
\hline & 2 & 0.12 & 0.09 & 0.09 & 0.12 & 0.1 & 0.16 & 0.11 & 0.11 & 0.12 & 0.09 & 0.1 & 0.51 \\
\hline & 3 & 0.11 & 0.11 & 0.08 & 0.1 & 0.12 & 0.11 & 0.1 & 0.09 & 0.1 & 0.12 & 0.1 & 0.11 \\
\hline & 4 & 0.12 & 0.08 & 0.14 & 0.17 & 0.25 & 0.31 & 0.28 & 0.09 & 0.1 & 0.14 & 0.11 & 0.59 \\
\hline \multirow{4}{*}{ 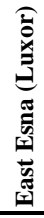 } & 5 & 1.07 & 2.71 & 0.08 & 0.1 & 0.09 & 0.14 & 0.27 & 0.13 & 0.15 & 0.1 & 0.1 & 0.11 \\
\hline & 6 & 1.67 & 3.58 & 1.02 & 2.08 & 1.08 & 1.1 & 1.38 & 0.11 & 0.13 & 1.12 & 1.11 & 1.16 \\
\hline & 7 & 0.45 & 0.12 & 0.29 & 0.37 & 1.01 & 0.33 & 0.37 & 0.35 & 0.32 & 0.27 & 0.18 & 0.33 \\
\hline & 8 & 0.84 & 0.19 & 0.06 & 0.09 & 0.18 & 0.23 & 0.15 & 0.12 & 0.11 & 0.17 & 0.17 & 0.56 \\
\hline \multirow{6}{*}{ 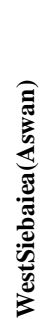 } & 9 & 0.37 & 0.11 & 0.28 & 0.3 & 0.35 & 0.31 & 0.26 & 0.28 & 0.31 & 0.38 & 0.35 & 0.31 \\
\hline & 10 & 0.14 & 0.11 & 0.13 & 0.16 & 0.14 & 0.2 & 0.13 & 0.13 & 0.16 & 0.27 & 0.23 & 0.34 \\
\hline & 11 & 0.16 & 0.1 & 0.08 & 0.09 & 0.16 & 0.13 & 0.11 & 0.09 & 0.12 & 0.13 & 0.13 & 0.15 \\
\hline & 12 & 0.11 & 0.13 & 0.06 & 0.11 & 0.87 & 0.2 & 0.11 & 0.09 & 0.12 & 0.1 & 0.09 & 0.31 \\
\hline & 13 & 0.11 & 0.1 & 0.06 & 0.19 & 0.1 & 0.11 & 0.18 & 0.07 & 0.1 & 0.12 & 0.09 & 0.48 \\
\hline & 14 & 0.14 & 0.1 & 0.06 & 0.09 & 0.14 & 0.15 & 0.12 & 0.11 & 0.13 & 0.16 & 0.11 & 1.29 \\
\hline
\end{tabular}

Table 3-1:- b Seasonal Mean For Manganese (II) For The Ground Water Samples Taken From West Esna(Luxor) Passing By Est Esna (Luxor) Finally By West Sebaeya (Aswan) (Oct.2014 - Sep. 2015 )

\begin{tabular}{|c|c|c|c|c|c|c|}
\hline \multicolumn{3}{|c|}{ Sample(weels) } & Autumn & Winter & Spring & Summer \\
\hline \multirow{2}{*}{$\begin{array}{l}0 \\
\overline{0} \\
0 \\
0 \\
0 \\
0 \\
0\end{array}$} & \multirow{2}{*}{ 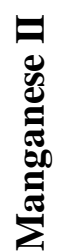 } & Min & 0.06 & 0.07 & 0.1 & 0.1 \\
\hline & & Max & 2.1 & 1.1 & 1.12 & 3.58 \\
\hline
\end{tabular}




\section{Manganese $\mathrm{Mn}(\mathrm{II})$}

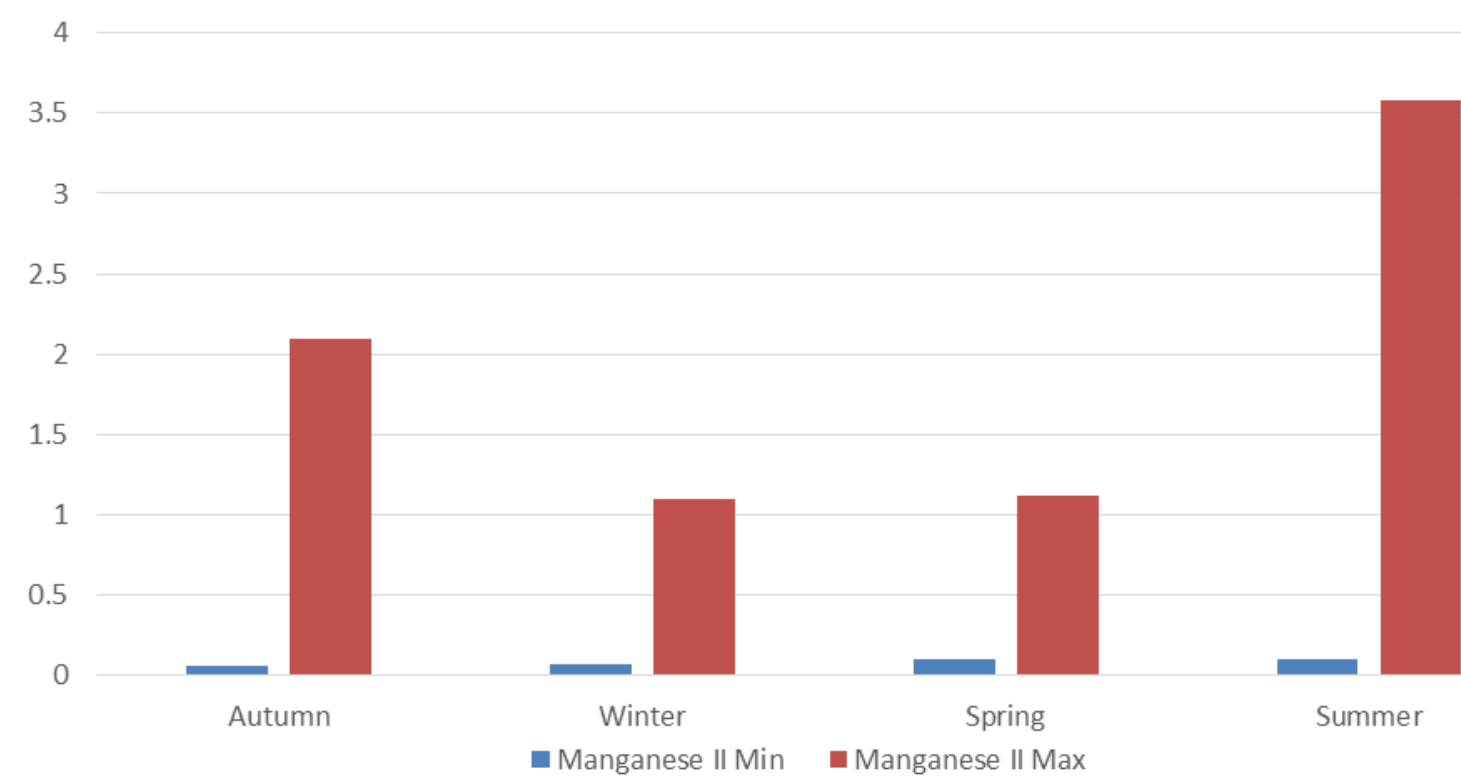

Figure 3-1:- seasonal mean for Mn

Table 3-2:- a Monthly Variation For Iron (II) For The Ground Water Samples Taken From West Esna(Luxor) Passing By Est Esna (Luxor) Finally By West Sebaeya (Aswan) (Oct.2014 - Sep. 2015)

\begin{tabular}{|c|c|c|c|c|c|c|c|c|c|c|c|c|c|}
\hline \multicolumn{2}{|c|}{ Sample(weels) } & October & November & December & January & Febrauray & Marsh & April & May & June & July & Augest & September \\
\hline \multirow{4}{*}{ 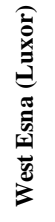 } & 1 & 10.09 & 5.37 & 7.1 & 1.36 & 3.21 & 2.95 & 0.49 & 1.71 & 2.08 & 0.85 & 0.84 & 1.51 \\
\hline & 2 & 2.93 & 2.82 & 0.22 & 2.75 & 176 & 6.01 & 1.51 & 1.83 & 2.14 & 0.42 & 0.52 & 1.38 \\
\hline & 3 & 2.21 & 7.85 & 0.25 & 2.42 & 3.2 & 4.59 & 0.75 & 2.01 & 2.19 & 0.22 & 0.67 & 3.82 \\
\hline & 4 & 4.32 & 1.19 & 4.39 & 8.01 & 8.71 & 2.41 & 0.39 & 1.21 & 1.32 & 1.59 & 1.41 & 1.02 \\
\hline \multirow{4}{*}{ 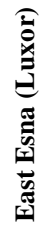 } & 5 & 2.53 & 5.1 & 0.24 & 1.86 & 0.91 & 9.18 & 6.15 & 2.35 & 2.88 & 0.2 & 1.51 & 2.82 \\
\hline & 6 & 2.03 & 4.12 & 1.74 & 5.37 & 3.62 & 2.96 & 0.93 & 5.75 & 5.62 & 3.63 & 0.82 & 1.51 \\
\hline & 7 & 1.62 & 3.84 & 0.25 & 6.01 & 1.25 & 3.87 & 1.58 & 1.45 & 1.44 & 0.39 & 3.02 & 0.42 \\
\hline & 8 & 29.2 & 3.04 & 0.2 & 0.69 & 6.57 & 6.83 & 2.42 & 0.77 & 0.97 & 2.35 & 0.68 & 5.88 \\
\hline \multirow{6}{*}{ 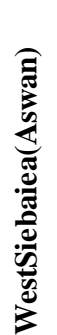 } & 9 & 1.27 & 1.25 & 0.23 & 1.93 & 1.42 & 591 & 0.35 & 0.43 & 0.47 & 3.88 & 0.45 & 0.89 \\
\hline & 10 & 1.85 & 1.41 & 0.18 & 8.34 & 2.11 & 8.07 & 1.79 & 0.47 & 0.55 & 44.4 & 1.93 & 4.41 \\
\hline & 11 & 2.24 & 1.84 & 0.34 & 1.56 & 2.25 & 4.09 & 1.24 & 0.87 & 1.01 & 1.26 & 0.46 & 1.41 \\
\hline & 12 & 4.13 & 2.01 & 0.27 & 1.08 & 1.27 & 2.47 & 0.69 & 1.45 & 1.64 & 0.91 & 1.3 & 0.85 \\
\hline & 13 & 1.99 & 1.63 & 0.27 & 0.97 & 0.88 & 2.63 & 4.99 & 2.01 & 2.15 & 1.06 & 0.53 & 0.86 \\
\hline & 14 & 1.83 & 2.03 & 0.21 & 1.59 & 1.21 & 2.72 & 3.99 & 2.04 & 2.35 & 3.28 & 0.44 & 2.86 \\
\hline
\end{tabular}


Table 3-2:- b Seasonal Mean For Iron (II) For The Ground Water Samples Taken From West Esna (Luxor) Passing By Est Esna (Luxor) Finally By West Sebaeya (Aswan) (Oct.2014 - Sep. 2015 )

\begin{tabular}{|c|c|c|c|c|c|c|}
\hline \multicolumn{3}{|c|}{ Sample(weels) } & Autumn & Winter & Spring & Summer \\
\hline$\frac{\mathscr{c}}{\bar{\sigma}}$ & \multirow{2}{*}{ 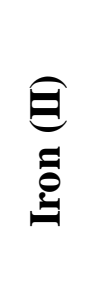 } & Min & 0.18 & 0.35 & 0.47 & 0.42 \\
\hline $\bar{\partial}$ & & Max & 8.1 & 9.83 & 2.88 & 10.09 \\
\hline
\end{tabular}

$$
\text { Iron Fe (II) }
$$

12

10

8

6

4

2

0

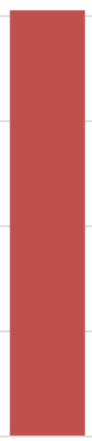

Autumn

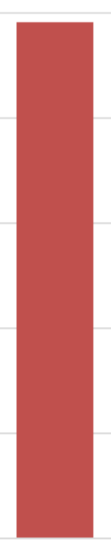

Winter

- Iron (II) Min घ Iron (II) Max

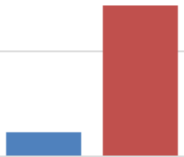

Spring

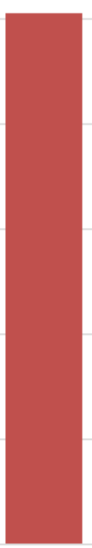

Summer

Figure 3-2:- seasonal mean for Fe 
Table 3-3:- a Monthly Variation For Cupper Cu(II) For The Ground Water Samples Taken From West Esna(Luxor) Passing By Est Esna (Luxor) Finally By West Sebaeya (Aswan) (Oct.2014 - Sep. 2015)

\begin{tabular}{|c|c|c|c|c|c|c|c|c|c|c|c|c|c|}
\hline \multicolumn{2}{|c|}{ Sample(weels) } & October & November & December & January & Febrauray & Marsh & April & May & June & July & Augest & September \\
\hline \multirow{4}{*}{ 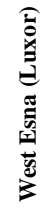 } & 1 & 0.19 & 0.1 & 0.09 & 0.04 & 0.03 & 0 & 0.18 & 0.05 & 0 & 0.06 & 0.03 & 0.06 \\
\hline & 2 & 0.14 & 0.02 & 0 & 0.05 & 0 & 0.07 & 0.13 & 0.02 & 0 & 0.02 & 0.05 & 0.01 \\
\hline & 3 & 0.08 & 0.09 & 0.02 & 0.11 & 0.06 & 0.05 & 0 & 0.07 & 0.06 & 0.02 & 0 & 0.06 \\
\hline & 4 & 0.06 & 0.01 & 0.07 & 0.06 & 0.08 & 0.04 & 0.02 & 0.01 & 0.03 & 0.04 & 0 & 0.05 \\
\hline \multirow{4}{*}{ 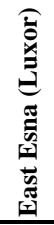 } & 5 & 0.09 & 0.2 & 0 & 0.03 & 0 & 0.07 & 0.02 & 0.05 & 0.07 & 0 & 0.02 & 0.04 \\
\hline & 6 & 0.04 & 0.11 & 0.05 & 0.03 & 0.06 & 0.09 & 0.01 & 0.14 & 0.14 & 0.12 & 0.04 & 0.05 \\
\hline & 7 & 0.02 & 0.05 & 0.03 & 0.14 & 0 & 0 & 0.05 & 0 & 0 & 0.05 & 0.08 & 0 \\
\hline & 8 & 0.14 & 0.16 & 0.03 & 0 & 0 & 0.02 & 0.02 & 0 & 0 & 0.04 & 0.08 & 0.06 \\
\hline \multirow{6}{*}{ 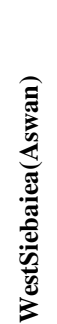 } & 9 & 0.07 & 0.03 & 0.03 & 0.07 & 0.04 & 0.07 & 0.05 & 0 & 0 & 0.12 & 0.02 & 0.04 \\
\hline & 10 & 0.06 & 0.05 & 0.03 & 0.07 & 0.03 & 0 & 0.02 & 0 & 0 & 0.07 & 0.05 & 0.05 \\
\hline & 11 & 0.06 & 0.1 & 0.02 & 0.02 & 0.03 & 0 & 0.04 & 0.04 & 0.06 & 0 & 0.03 & 0.68 \\
\hline & 12 & 0.13 & 0.12 & 0.03 & 0.01 & 0.07 & 0.02 & 0 & 0 & 0 & 0.03 & 0.06 & 0.12 \\
\hline & 13 & 0.1 & 0.07 & 0.05 & 0 & 0.01 & 0 & 0.03 & 0.02 & 0.04 & 0.01 & 0.05 & 0.08 \\
\hline & 14 & 0.07 & 0.08 & 0.04 & 0.09 & 0.07 & 0.07 & 0.1 & 0.04 & 0.06 & 0.19 & 0 & 0.12 \\
\hline
\end{tabular}

Table 3-3:- b Seasonal Mean For Cupper Cu(II) For The Ground Water Samples Taken From West Esna(Luxor) Passing By Est Esna (Luxor) Finally By West Sebaeya (Aswan) (Oct.2014 - Sep. 2015 )

\begin{tabular}{|c|c|c|c|c|c|c|}
\hline \multicolumn{3}{|c|}{ Sample(weels) } & Autumn & Winter & Spring & Summer \\
\hline \multirow{2}{*}{ 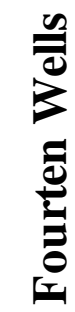 } & \multirow{2}{*}{ 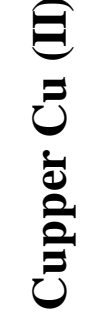 } & Min & 0.01 & 0.01 & 0.02 & 0.01 \\
\hline & & Max & 0.15 & 0.18 & 0.19 & 0.19 \\
\hline
\end{tabular}




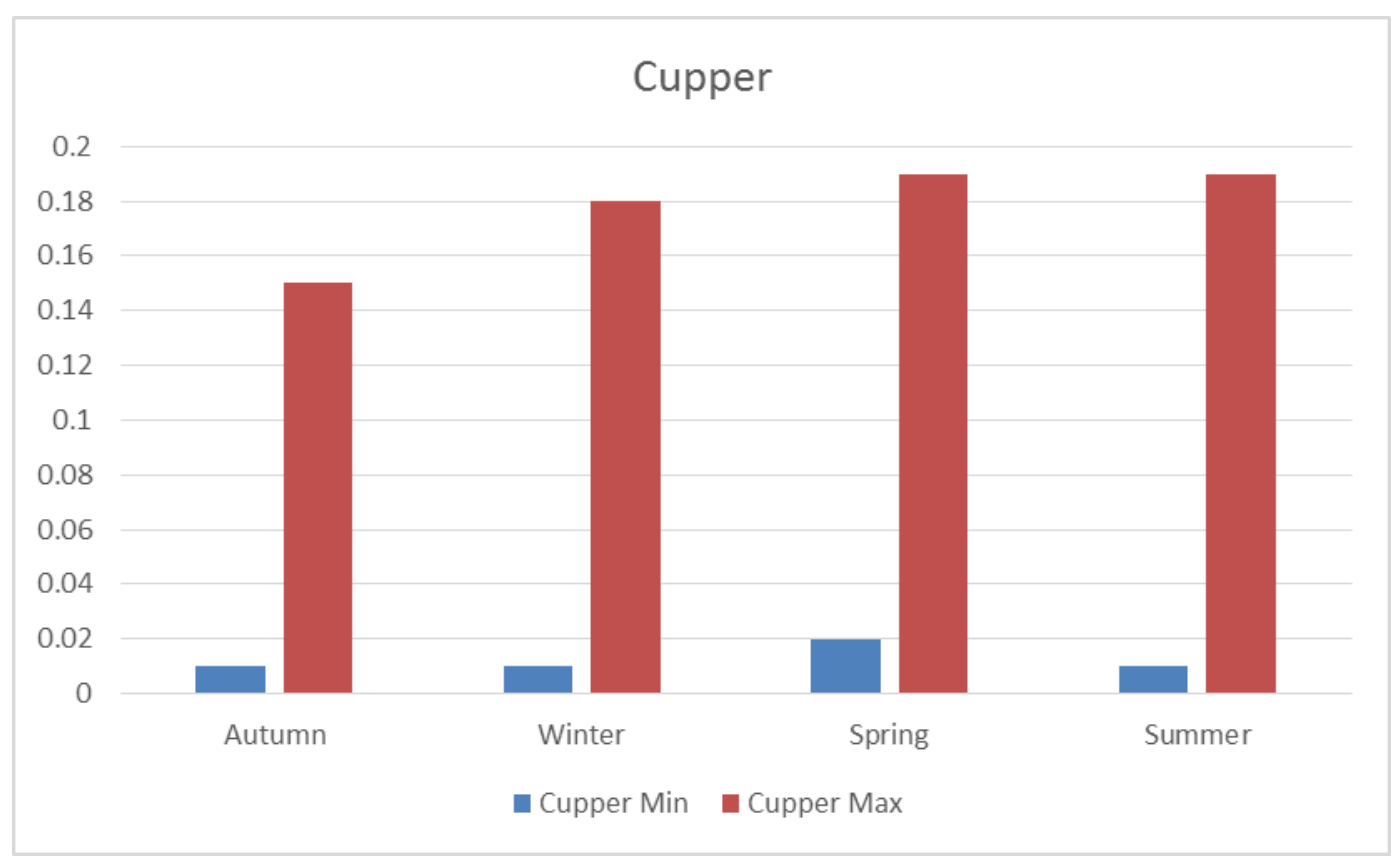

Figure 3-3:- seasonal mean for $\mathrm{Cu}$

Table 3-4:- a Monthly Variation For Zinc Zn(II) For The Ground Water Samples Taken From West Esna(Luxor) Passing By Est Esna (Luxor) Finally By West Sebaeya (Aswan) (Oct.2014 - Sep. 2015 )

\begin{tabular}{|c|c|c|c|c|c|c|c|c|c|c|c|c|c|}
\hline \multicolumn{2}{|c|}{ Sample(weels) } & October & November & December & January & Febrauray & Marsh & April & May & June & July & Augest & September \\
\hline \multirow{4}{*}{ 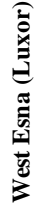 } & 1 & 0.45 & 0.15 & 0.21 & 0.1 & 0.09 & 0.07 & 0.15 & 2.25 & 2.35 & 1.36 & 0.85 & 0.11 \\
\hline & 2 & 0.14 & 0.1 & 0.06 & 0.11 & 0.07 & 0.12 & 0.12 & 0.22 & 0.24 & 0.06 & 1.74 & 0.05 \\
\hline & 3 & 0.14 & 0.1 & 0.09 & 0.09 & 0.07 & 0.09 & 0.08 & 0.85 & 0.63 & 0.06 & 0.36 & 0.04 \\
\hline & 4 & 0.19 & 0.1 & 0.15 & 0.1 & 0.09 & 0.08 & 0.08 & 0.24 & 0.28 & 9.61 & 5.3 & 0.03 \\
\hline \multirow{4}{*}{ 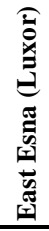 } & 5 & 0.16 & 0.27 & 0.11 & 0.17 & 0.14 & 0.03 & 0.31 & 5.35 & 6.73 & 9.43 & 7.82 & 0.09 \\
\hline & 6 & 0.15 & 0.26 & 0.11 & 0.18 & 0.09 & 0.06 & 0.14 & 0.35 & 0.18 & 10.79 & 5.85 & 0.02 \\
\hline & 7 & 0.16 & 0.18 & 0.08 & 0.23 & 0.12 & 0.07 & 0.13 & 0.17 & 0.09 & 2.35 & 1.03 & 0.06 \\
\hline & 8 & 6.67 & 0.45 & 0.12 & 0.08 & 0.11 & 0.09 & 7.72 & 0.05 & 0.07 & 0.11 & 4.38 & 0.28 \\
\hline \multirow{6}{*}{ 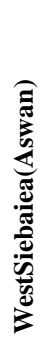 } & 9 & 5.86 & 0.16 & 0.15 & 0.22 & 0.34 & 1.01 & 0.21 & 0.28 & 0.34 & 11.22 & 7.61 & 0.32 \\
\hline & 10 & 0.31 & 0.17 & 0.11 & 0.11 & 0.26 & 0.25 & 4.52 & 3.21 & 4.88 & 11.32 & 8.31 & 0.18 \\
\hline & 11 & 5.66 & 0.1 & 0.15 & 0.13 & 0.41 & 0.09 & 0.19 & 0.96 & 1.04 & 7.93 & 0.22 & 0.14 \\
\hline & 12 & 0.52 & 0.19 & 0.13 & 0.09 & 0.12 & 0.16 & 0.59 & 2.81 & 3.13 & 9.53 & 0.45 & 0.21 \\
\hline & 13 & 0.23 & 0.19 & 0.12 & 0.12 & 0.17 & 0.15 & 0.43 & 0.25 & 0.33 & 4.72 & 0.18 & 0.19 \\
\hline & 14 & 2.8 & 0.18 & 0.12 & 0.24 & 0.17 & 0.16 & 8.13 & 8.3 & 9.22 & 11.11 & 2.53 & 0.14 \\
\hline
\end{tabular}


Table 3-4:- b Seasonal Mean For Zinc Zn(II) For The Ground Water Samples Taken From West Esna(Luxor) Passing By Est Esna (Luxor) Finally By West Sebaeya (Aswan) (Oct.2014 - Sep. 2015)

\begin{tabular}{|c|c|c|c|c|c|c|}
\hline \multicolumn{3}{|c|}{ Sample(weels) } & Autumn & Winter & Spring & Summer \\
\hline$\frac{20}{\overline{0}}$ & \multirow{2}{*}{ 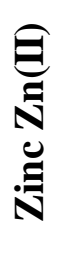 } & Min & 0.06 & 0.06 & 0.06 & 0.02 \\
\hline छ & & Max & 0.41 & 8.13 & 11.32 & 6.67 \\
\hline
\end{tabular}

\section{Zinc Zn (II)}

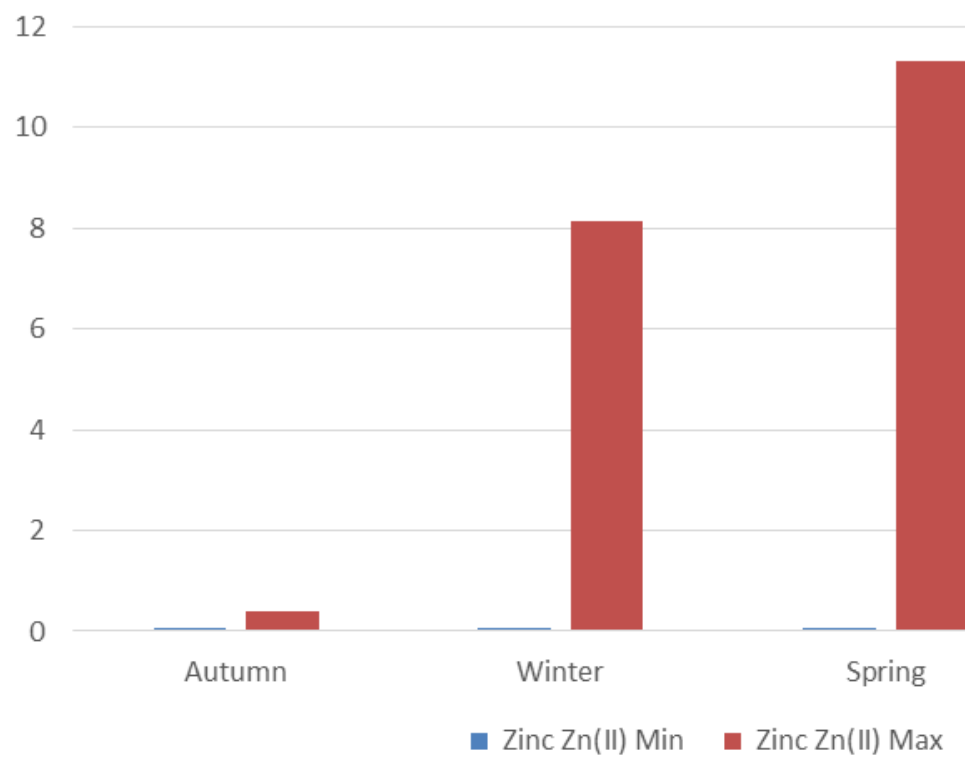

Figure 3-4:- seasonal mean for $\mathrm{Zn}$ 
Table 3-5:- aMonthly Variation For Cadmium Cd (II) For The Ground Water Samples Takes From West Esna(Luxor) Passing By Est Esna (Luxor) Finally By West Sebaeya (Aswan) (Oct.2014 - Sep. 2015 )

\begin{tabular}{|c|c|c|c|c|c|c|c|c|c|c|c|c|c|}
\hline \multicolumn{2}{|c|}{ Sample(weels) } & October & November & December & January & Febrauray & Marsh & April & May & June & July & Augest & September \\
\hline \multirow{4}{*}{ 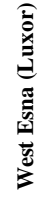 } & 1 & 0.04 & 0.02 & 0.03 & 0.14 & 0.3 & 0.11 & 0.14 & 0.08 & 0.09 & 0.1 & 0.11 & 0.12 \\
\hline & 2 & 0.05 & 0 & 0 & 0.14 & 0.11 & 0.11 & 0.1 & 0.06 & 0.07 & 0.07 & 0.1 & 0.31 \\
\hline & 3 & 0.02 & 0.4 & 0.02 & 0.13 & 0.12 & 0.09 & 0.1 & 0.09 & 0.12 & 0.06 & 0.09 & 0.11 \\
\hline & 4 & 0.03 & 0.04 & 0.02 & 0.12 & 0.28 & 0.09 & 0.1 & 0.11 & 0.14 & 0.07 & 0.1 & 0.11 \\
\hline \multirow{4}{*}{ 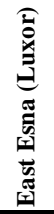 } & 5 & 0.02 & 0.03 & 0.01 & 0.15 & 0.12 & 0.19 & 0.09 & 0.09 & 0.12 & 0.08 & 0.08 & 0.07 \\
\hline & 6 & 0.03 & 0.04 & 0.04 & 0.19 & 0.14 & 0.11 & 0.22 & 0.07 & 0.09 & 0.1 & 0.08 & 0.07 \\
\hline & 7 & 0.04 & 0.01 & 0.01 & 0.28 & 0.2 & 0.15 & 0.12 & 0.08 & 0.1 & 0.09 & 0.08 & 0.06 \\
\hline & 8 & 0.02 & 0.02 & 0.02 & 0.13 & 0.09 & 0.11 & 0.07 & 0.07 & 0.09 & 0.06 & 0.1 & 0.36 \\
\hline \multirow{6}{*}{ 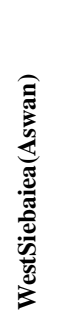 } & 9 & 0.06 & 0.02 & 0.03 & 0.16 & 0.15 & 0.11 & 0.14 & 0.09 & 0.11 & 0.12 & 0.1 & 0.1 \\
\hline & 10 & 0.02 & 0.03 & 0 & 0.1 & 0.1 & 0.1 & 0.11 & 0.07 & 0.09 & 0.11 & 0.06 & 0.06 \\
\hline & 11 & 0.03 & 0.01 & 0 & 0.12 & 0.12 & 0.09 & 0.08 & 0.08 & 0.1 & 0.09 & 0.06 & 0.06 \\
\hline & 12 & 0.03 & 0.05 & 0 & 0.17 & 0.21 & 0.12 & 0.11 & 0.06 & 0.08 & 0.08 & 0.02 & 0.08 \\
\hline & 13 & 0 & 1.04 & 0 & 0.13 & 0.11 & 0.09 & 0.09 & 0.04 & 0.06 & 0.08 & 0 & 0.43 \\
\hline & 14 & 0.05 & 0.02 & 0.15 & 0.13 & 0.12 & 0.17 & 0.11 & 0.1 & 0.12 & 0.1 & 0.09 & 0.22 \\
\hline
\end{tabular}

Table 3-5:- b Seasonal Mean For Cadmium Cd(II) For The Ground Water Samples Taken From West Esna(Luxor) Passing By Est Esna (Luxor) Finally By West Sebaeya (Aswan) (Oct.2014 - Sep. 2015)

\begin{tabular}{|c|c|c|c|c|c|c|}
\hline \multicolumn{3}{|c|}{ Sample(weels) } & Autumn & Winter & Spring & Summer \\
\hline \multirow{2}{*}{ 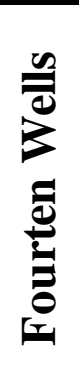 } & \multirow{2}{*}{ 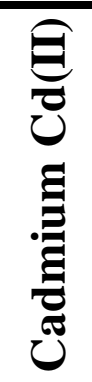 } & Min & 0 & 0 & 0.04 & 0 \\
\hline & & Max & 0.31 & 0.28 & 0.22 & 0.14 \\
\hline
\end{tabular}




\section{Cadmium}

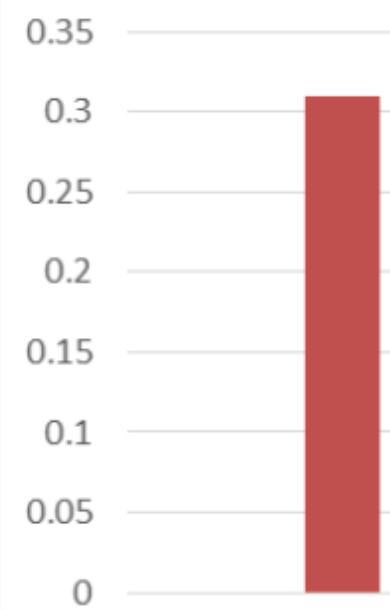

Autumn

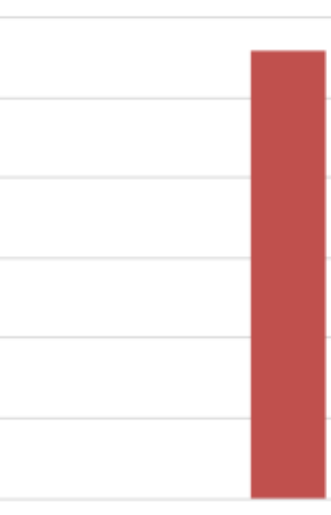

Winter

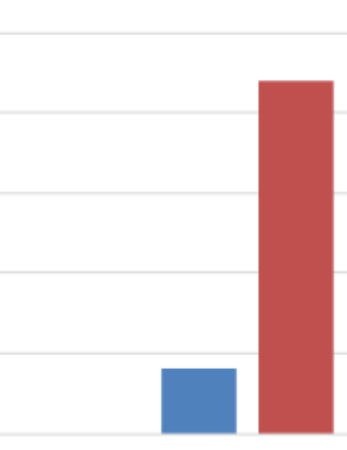

Spring

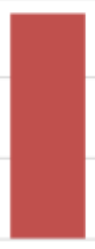

Summer

- Cadmium Cd(II) Min a Cadmium Cd(II) Max

Figure 3-5:- seasonal mean for $\mathrm{Cd}$

Table 3-6:- a Monthly Variation For Lead Pb (II) For The Ground Water Samples Taken From West Esna(Luxor) Passing By Est Esna (Luxor) Finally By West Sebaeya (Aswan) (Oct.2014 - Sep. 2015)

\begin{tabular}{|c|c|c|c|c|c|c|c|c|c|c|c|c|c|}
\hline \multicolumn{2}{|c|}{ Sample(weels) } & October & November & December & January & Febrauray & Marsh & April & May & June & July & Augest & September \\
\hline \multirow{4}{*}{ 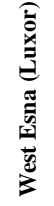 } & 1 & 0 & 0.21 & 0 & 0 & 10.33 & 0.25 & 0.34 & 0.11 & 0.12 & 0 & 0.18 & 5.85 \\
\hline & 2 & 0 & 0 & 0 & 0 & 0.22 & 1.22 & 0.66 & 0.12 & 0.13 & 0 & 0.17 & 2.45 \\
\hline & 3 & 0 & 0.42 & 0 & 2.71 & 4.3 & 0.11 & 0.48 & 0.22 & 0.21 & 0.11 & 0 & 3.01 \\
\hline & 4 & 0 & 0.21 & 0 & 0 & 0.25 & 1.35 & 1.4 & 0.1 & 0.11 & 0 & 0.18 & 1.98 \\
\hline \multirow{4}{*}{ 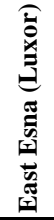 } & 5 & 0 & 0 & 0 & 1.01 & 1.22 & 0.61 & 0.53 & 0.18 & 0.2 & 0.18 & 0.26 & 0.21 \\
\hline & 6 & 0 & 0.41 & 0 & 5.8 & 1.61 & 0.55 & 3.44 & 0 & 0 & 0.28 & 0.26 & 3.37 \\
\hline & 7 & 0 & 0 & 0 & 1.01 & 2.42 & 8.69 & 0 & 0.23 & 0.26 & 0 & 0.2 & 0.23 \\
\hline & 8 & 0 & 0.98 & 0 & 0 & 0 & 0.14 & 0.12 & 0.19 & 0.21 & 0 & 0.33 & 1.76 \\
\hline \multirow{6}{*}{ 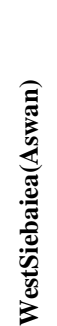 } & 9 & 0 & 2.44 & 0 & 1.28 & 3.51 & 0.41 & 0.17 & 0.45 & 0.53 & 0.11 & 0.25 & 0.22 \\
\hline & 10 & 0 & 0.16 & 0 & 2.56 & 0.24 & 0.33 & 0.17 & 0 & 0 & 0.3 & 0.21 & 0.18 \\
\hline & 11 & 0 & 0 & 0 & 0 & 0.3 & 0 & 0.12 & 0 & 0 & 0 & 0.11 & 2.73 \\
\hline & 12 & 0 & 14.8 & 0 & 2.56 & 0.42 & 3.4 & 0.17 & 0 & 0 & 0.15 & 0.11 & 4.15 \\
\hline & 13 & 0 & 1.61 & 0 & 5.09 & 3.68 & 0.33 & 0.19 & 0.11 & 0.12 & 0.11 & 0.05 & 0.3 \\
\hline & 14 & 0.2 & 0.52 & 0 & 2.72 & 3.63 & 4.03 & 0.27 & 0.21 & 0.23 & 0.2 & 0.1 & 5.33 \\
\hline
\end{tabular}


Table 3-6:- b Seasonal Mean For Lead Pb(II) For The Ground Water Samples Taken From West Esna(Luxor) Passing By Est Esna (Luxor) Finally By West Sebaeya (Aswan) (Oct.2014 - Sep. 2015 )
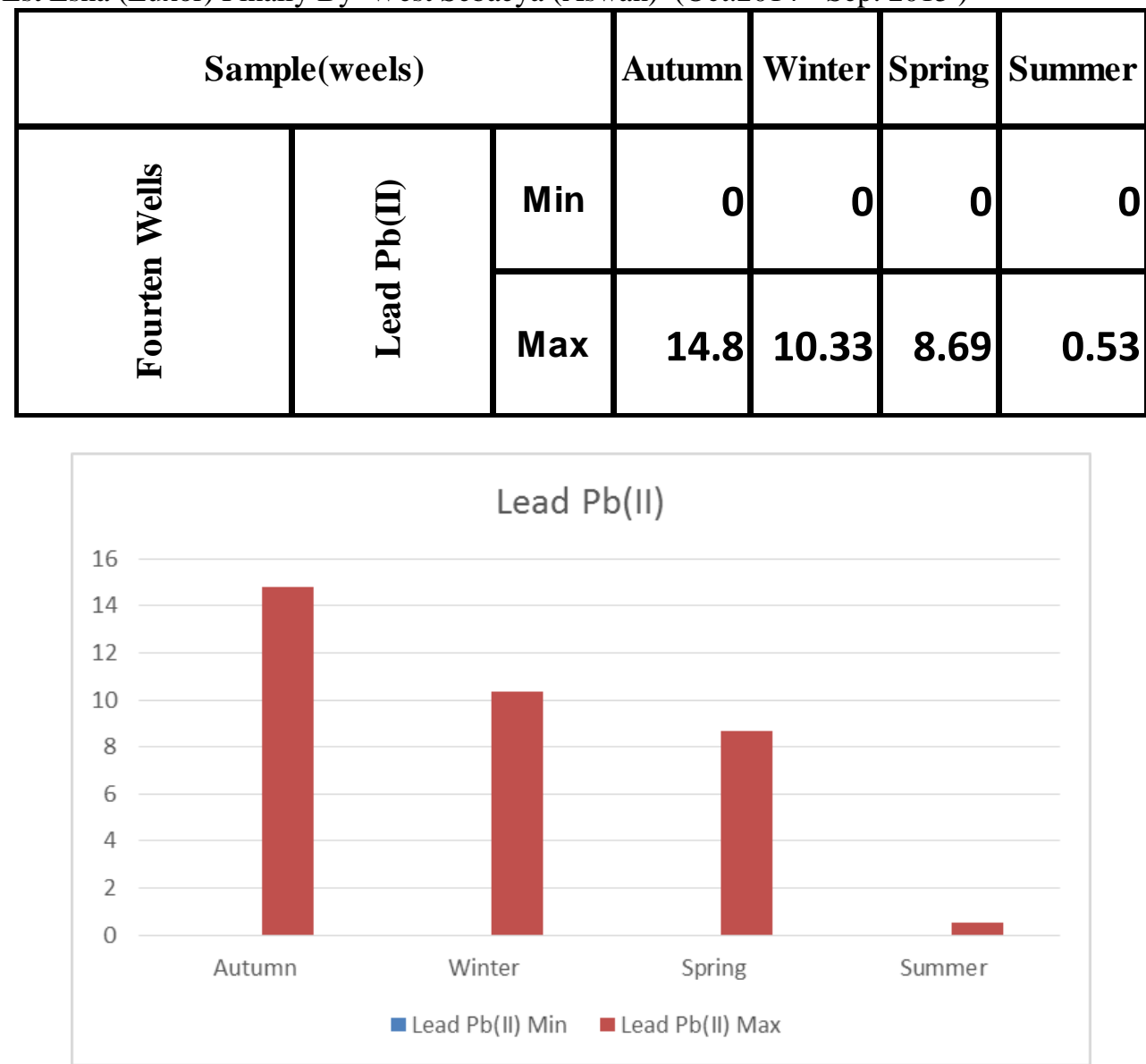

Figure 3-6:- seasonal mean for $\mathrm{Pb}$

\section{Conclusions and Recommendations:-}

The aims of this work determine the heavy metals found in the ground water of upper egypt in the area between Esna of luxor governorate to Al-sebaya of Aswan governorate.. The source of these heavy metals was from the ground rock found nearest to the natural water. Having entrance of those heavy metals in the body of peoples my leads to different health risks such as cancer, kidney problem, nausea, high blood pressure. Atomic Absorption Spectroscopy (AAS) used to determine the concentrations of heavy metals under study $(\mathrm{Mn}, \mathrm{Fe}, \mathrm{Cu}, \mathrm{Zn}, \mathrm{Cd}$ and $\mathrm{Pb})$. The concentrations of four metals ( $\mathrm{Mn}, \mathrm{Fe}, \mathrm{Cd}$, and $\mathrm{Pb}$ ) are higher than the allowed WHO limits. Iron and lead have the highest risk of high altitude of $100 \%$ above the permissible limits. Municipal waste, landfills, cesspits, and incineration of solid wastes in the study area are responsible for the occurrence of the trace metals detected in the groundwater of the study area. It is concluded that un- controlled consumption of groundwater which is used for drinking in the study area may be dangerous for human health. Our recommendations are that uncontrolled disposal of wastes and incineration of solid waste should be banned and responsible authorities have to monitor and control the quality of groundwater periodically (e.g. heavy metals content) in the area under study.

\section{References:-}

1. G. Bassioni, K.Ashraf, A.Abd Elhameed, Risk assessment using ICP-MS of heavy metals in groundwater in Upper Egypt ,Journal of Natural Resources and Development, Vol. 5 2015, 65-70

2. M. A. Momodu and C. A. Anyakora, "Heavy Metal Con- tamination of Ground Water: The Surulere Case Study,"Research Journal Environmental and Earth Sciences, Vol. 2, No. 1, 2010, 39-43.

3. J. K. Vodela, J. A. Renden, S. D. Lenz, W. H. Mchel Henney and B. W. Kemppainen, "Drinking Water Contaminates," Poultry Science, Vol. 76, No. 11, 1997,. 1474-1492.

4. W. R. Mason, "Groundwater pollution, prevention and control," Environ. Manage. Issues, 2012 
5. United States Environmental Protection Agency (US EPA). 2012 Edition of the Drinking Water Standards and Health Advisories. Office of Water U.S. Environmental Protection Agency Washington, DC, pp. 1-10, 2012.

6. G. R. Bhagure, S. R. Mirgane. Heavy metal concentrations in groundwaters and soils of Thane Region of Maharashtra, India. Environ Monit Assess. 2011,173, 643-652.

7. A. G. Vaishaly,B. B. Mathew* and N.B. Krishnamurthy Health effects caused by metal contaminated ground water International Journal of Advances in Scientific Research 2015; 1(02): 60-64.

8. D. J. Ferner, "Toxicity and Heavy Metals," eMedicine Journal, Vol. 2, No. 5, 2001, p. 1.

9. D. Dupler, "Heavy Metal Poisoning," In: J. L. Longe, Ed., Gale Encyclopedia of Alternative Medicine, Gale Group, Farmington Hills, 2001, 2054-2057

10. Z. L. He, XE Yang, PJ Stoffella. Trace elements in agroecosystems and impacts on the environment. J Trace Elem Med Biol.19, 2005; 125-140

11. Egyptian Environmental Affairs Agency (EEAA) Law Number 48 of 1982 Promulgating the Environmental Law. Regulations to the Minister of Water Resources and Irrigation, 2009.

12. H. Mohammed, S. Sadeek, A.R.Mahmoud, D Zaky ,Comparison of AAS, EDXRF, ICP-MS and INAA performance for determination of selected heavy metals in HFO ashes Microchemical Journal 128 (2016) 1-6

13. J. H. Duffus. Heavy metals-a meaningless term Pure Appl Chem. 2002; 74(5):793-807.

14. L. Belkhiria, L. Mounib , T. S. Naranyc , A. Tiria, Evaluation of potential health risk of heavy metals in groundwater using the integration of indicator kriging and multivariate statistical methodsGroundwater for Sustainable Development 4 (2017) 12-22

15. I. Abdelfattah, A.A. Ismail, F.Al Sayed, A.Almedolab, K.M. Aboelghait, Biosorption of heavy metals ions in real industrial wastewater using peanut husk as efficient and cost effective adsorbent Environmental Nanotechnology, Monitoring \& Management 6 (2016) 176-183

16. Guidelines for drinking water quality, second ed.vol.2.Health criteria and other supporting information, Geneva, WHO (1996).

17. V. Vella, , R. Malaguarnera, , R. Lappano, M. Maggiolini, A. Belfiore, Recent views of heavy metals as possible risk factors and potential preventive and therapeutic agents in prostate cance Molecular and Cellular Endocrinology (2016) 1-16.

18. W. E. Achanzar, B. A Diwan, J Liu, S.T Quader, M. M Webber, M. P Waalkes, 2001. Cadmium-induced malignant transformation of human prostate epithelial cells. Cancer Res. 61, 455-458

19. S. Muhammad, T. Shah, S. Khan, Health risk assessment of heavy metals and their source apportionment in drinking water of Kohistan region, northern Pakistan,Microchemical Journal 98 (2011) 334-343

20. D. Xing, L. Guangyang, Q. Fangshu, L. Kai, S. Shao, L. Guibai, H. Liang, Removal of iron, manganese and ammonia from groundwater using a PAC-MBR system: The anti-pollution ability, microbial population and membrane fouling Desalination 403 (2017) 97-106

21. C. Li, S. Wang, X. Du, X. Cheng, M. Fu, N. Hou, D. Li, Immobilization of iron- and manganese-oxidizing bacteria with a biofilm-forming bacterium for the effective removal of iron and manganese from groundwater Bioresource Technology 220 (2016) 76-84

22. W. Huang, C.-D. Dong, C. Chen, R. Surampalli, Application of sulfate reduction mechanisms for the simultaneous bioremediation of toluene and copper contaminated groundwaterhih-Ming Kao International Biodeterioration \& Biodegradation xxx (2017) $1 \mathrm{e} 8$.

23. H. Pullin, R. A. Crane, D. J. Morgan, T. B. Scott, The effect of common groundwater anions on the aqueous corrosion of zero-valent iron nanoparticles and associated removal of aqueous copper and zinc Journal of Environmental Chemical Engineering 5 (2017) 1166-1173.

24. W. Chunfa, L. Yongming, S. Deng, Y. Teng, J. Song Spatial characteristics of cadmium in topsoils in a typical e-waste recycling area in southeast China and its potential threat to shallow, groundwater Science of the Total Environment 472 (2014) 556-561.

25. F. Rongbing, Y. Yang, X. Zhen, X. Zhang, X. Guo, B. Dongsu, The removal of chromium (VI) and lead (II) from groundwater using sepiolite-supported nanoscale zero-valent iron (S-NZVI) Chemosphere 138 (2015) 726-734. 